\title{
Cost analysis for Construction of Photovoltaic Roofing
}

\author{
Alena Tažiková, Zuzana Struková, Juraj Talian, Anna Ficiková
}

Faculty of Civil Engineering / Technical University of Kosice, Slovakia

\begin{abstract}
The article deals with roof building structures that allow the use of solar energy in the segment of family houses. Modern technologies include photovoltaic roofing, which, in addition to the production of electricity, also fully replaces the roofing itself. It does not disturb the resulting aesthetic and architectural impression of the roof. The article analyzes the cost, return on investment and service life of four solar solutions that are applied to the roof structure of a family house. The use of solar energy is currently small in the segment of family houses in Slovakia despite state subsidies. As this is an ecological way of obtaining energy, there is a need for more discussion on this topic in order to ensure the sustainability of the planet.
\end{abstract}

Keywords - solar energy, photovoltaic roofing, costs, return on investment, service life

\section{Introduction}

Energy is an essential part of everyday life, and it was necessary to use energy for all the successes of humanity. Energy is part of the economy, and the environment affects our daily lives [1]. It is important in developing civilization and it is a major topic in politics and diplomacy around the world [2].

DOI: 10.18421/TEM94-25

https://doi.org/10.18421/TEM94-25

Corresponding author: Alena Tažiková, Technical University of Košice, Faculty of Civil Engineering, Vysokoškolská 4, 04200 Košice, Slovakia, EU.

Email: alena.tazikova@tuke.sk

Received: 10 September 2020.

Revised: 20 October 2020.

Accepted: 27 October 2020.

Published: 27 November 2020.

(c))BY-Nc-ND (C) 2020 Alena Tažiková et al; published by UIKTEN. This work is licensed under the Creative Commons Attribution-NonCommercial-NoDerivs 4.0 License.

The article is published with Open Access at www.temjournal.com
In Sweden, for example, algorithms have been proposed to model final energy consumption. As a result, it is claimed that these algorithms can reduce the annual net cost to the end-user by $3-26 \%$ [3]. The goal of many countries' strategies is to increase solar electricity production by 2050 in order to meet their commitments under the Paris Agreement [4]. Penetration of solar photovoltaic systems in Watts per Capita, in 2018, is shown in Figure1. The installation of the solar panels themselves, as in Switzerland and also in Slovakia, is sensitive to the government's financial incentives. Solar panels located on the building can be connected to an intelligent grid for the distribution of energy produced, as well as to batteries for storing the energy produced. In this way, costs and emissions are reduced. At present, there is a high interest in the use of alternative energy sources due to the saving of solid fuels and energy raw materials that are being spent. One of these alternative renewable energy sources is photovoltaics, which uses energy from the sun. Properly used solar energy conversion systems cover $100 \%$ of a house's energy requirements and convert the house into a Net Zero Energy Building (NZEB) [5].

Modern technologies include photovoltaic roofing, which, in addition to the production of electricity, also fully replaces the roofing itself, takes over its properties and functions, does not disturb the resulting aesthetic and architectural impression of the roof. Electricity generation technology is directly integrated into the roofing itself. The price of photovoltaic equipment has dropped to a level where photovoltaics are advantageous and electricity produced on its own roof is cheaper than purchased. Similarly, in the world, several sources mention the possibilities of integrating photovoltaic technology into building structures without aesthetic intervention in the architecture. There is talk of the so-called solar architecture with integrated photovoltaics that helps solve global environmental problems [6]. Similarly, there is a current effort to continuously increase the efficiency of these photovoltaic systems [7]. 


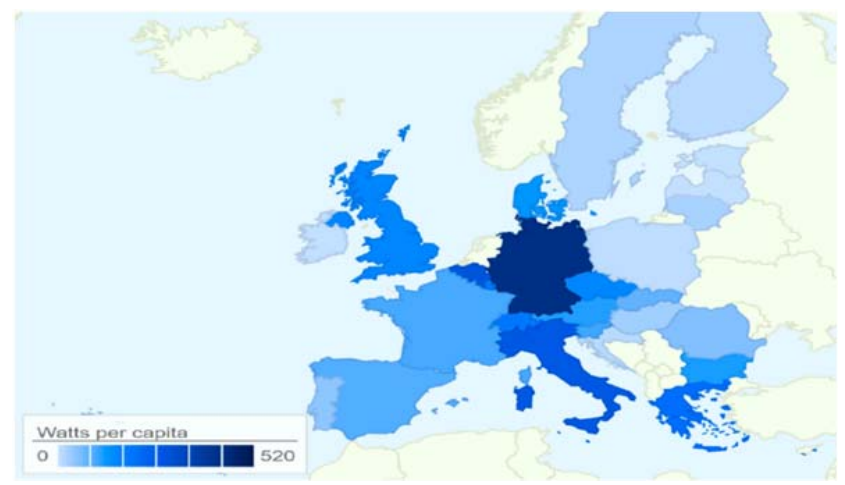

Figure 1. Penetration of solar photovoltaic systems, in Watts per Capita, in 2018 [4].

In Slovakia, it is currently possible to obtain subsidies from the state, which are limited. They increase the attractiveness of building a photovoltaic power plant. In the design of a photovoltaic power plant, where the annual amount of electricity produced is approximately equal to the amount of electricity consumed, only $25 \%$ of the electricity produced is consumed in the household and the rest goes to the distribution network. The consumption itself can be increased by switching on the appliances at the time of the highest intensity of solar radiation or by orienting the photovoltaics to the east or west, what balances the output during the day [8], [9]. The calculation of electricity yield is mainly influenced by the orientation and inclination of the panels, the type of panel, and the locality. Ideally oriented photovoltaic field of panels with an output of $1 \mathrm{kWp}$ in the environment of Slovakia will produce $930-$ $1050 \mathrm{kWh}$ per year. The ideal conditions for the production of electricity from photovoltaic panels are direct sunlight and an ambient temperature $25^{\circ} \mathrm{C}$. An increase in the temperature of the panels by $1{ }^{\circ} \mathrm{C}$ represents a decrease in its output by about $0.4 \%$. The average annual total of global solar radiation in Slovakia is shown in Fig. 2. The produced electricity will cover a large part of the domestic electricity consumption for family houses, while the differences between southern and northern Slovakia are minimal. In this way can save the household hundreds of euros a year.

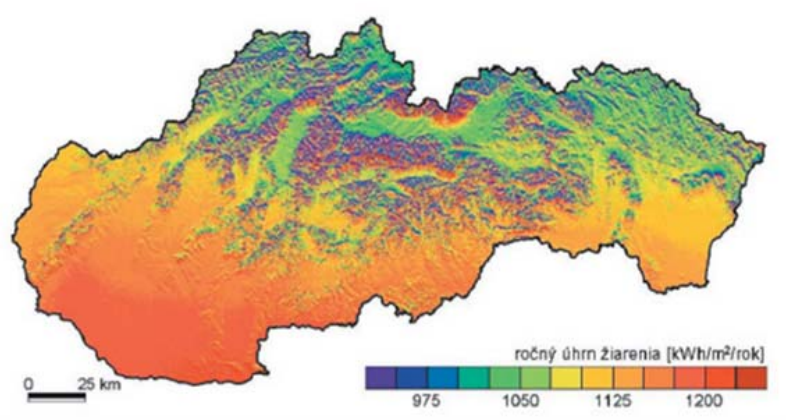

Figure 2. Average annual total of global solar radiation in Slovakia
Photovoltaic roofing is a new type of roofing. Photovoltaics, integrated into the roofing, with its simple installation and pleasant appearance, competes not only with the solar panel but also with conventional roofing. In the past, it was more expensive than conventional photovoltaics panels, but now it is more affordable and is a pleasant alternative type of roofing that saves electricity bills [10], [11]. This covering fulfills the function of covering the building, protects it from weather conditions and at the same time participates in the production of electricity. Like solar panels, it uses the sun as a source of energy. It is therefore an interesting way to replace solar collectors located on the roofing. It eliminates damage to the roofing during installation, improves the overall aesthetic result of the roof and is not difficult to maintain.

\section{Materials and Methodology}

We know three variants of photovoltaic roofing. First variant is a roofing in the form of photovoltaic strips, the second variant is photovoltaic tile and the last variant is photovoltaic modules. It is important to note that it is not necessary to cover the entire roof area with photovoltaic roofing. Like solar collectors, photovoltaic roofing is placed only on the southfacing part of the roof. The amount of photovoltaic roofing use depends on many factors. It depends on the type of installed photovoltaic roofing (monocrystalline, polycrystalline, amorphous silicon), on the way of using the obtained electric energy (water heating, electrical appliances, heating), on the number of persons in the household and last but not least from the locality [12], [13]. A market survey was conducted in Slovakia to find out which companies offer photovoltaic roofing in the Slovak Republic. Subsequently, the project of a family house in the selected locality was selected, within which five types of roofing were compared, namely ceramic roofing, solar collectors, photovoltaic roof modules and photovoltaic roofing in combination with the selected ceramic roofing. Roof coverage was compared according to different aspects and criteria. Based on the comparison performed on a specific example, it is possible to determine its suitability and usability, to point out its advantages and disadvantages.

Project of a family house is shown in the picture Fig.3, Fig.4. In order to be able to objectively compare selected products and services, it is necessary to use the example of a specific family house located on a specific area. It is a detached single-storey non-basement family house designed for five people. The layout of the family house is shown in Fig. 3 


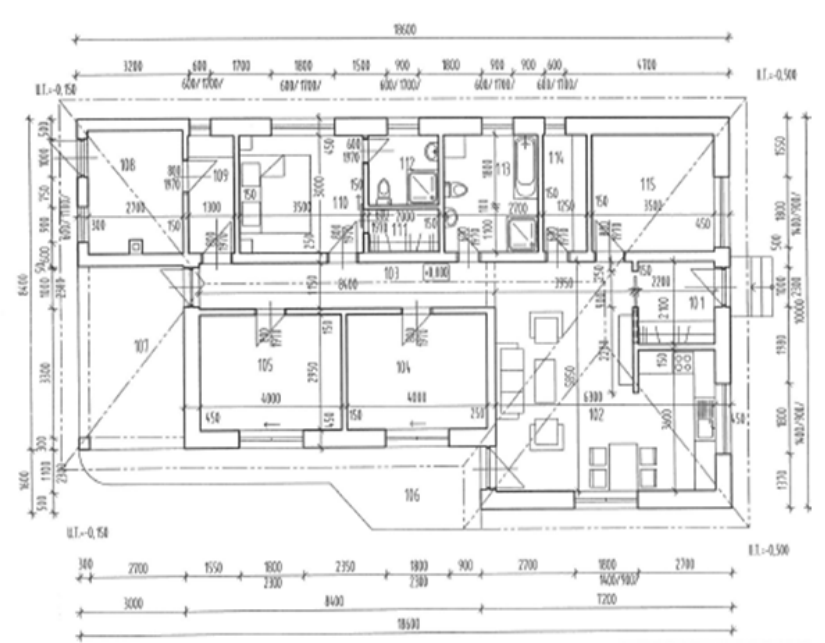

Figure 3. Floor plan of the $1^{\text {st }}$ floor

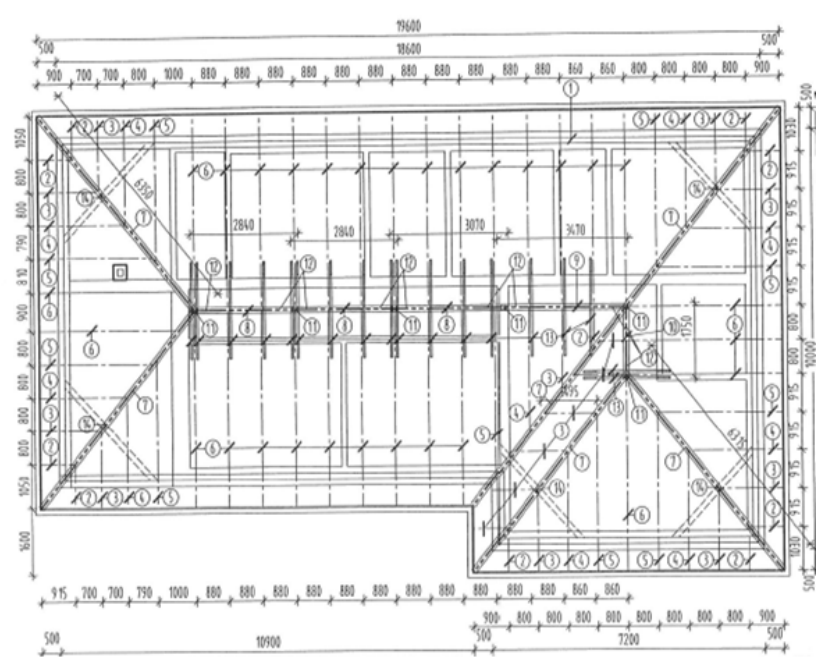

Figure 4. Floor plan of the truss

In the family house, we count on a photovoltaic power plant with an output of $2.55 \mathrm{kWp}$, which will produce $2,500 \mathrm{kWh}$ of electricity per year. The own energy consumption will be $100 \%$. Photovoltaic roofing / solar collectors will be placed on a part of the roof structure facing south. Location: The family house, which is used for comparison, is located in eastern Slovakia in Humenné Fig.5.

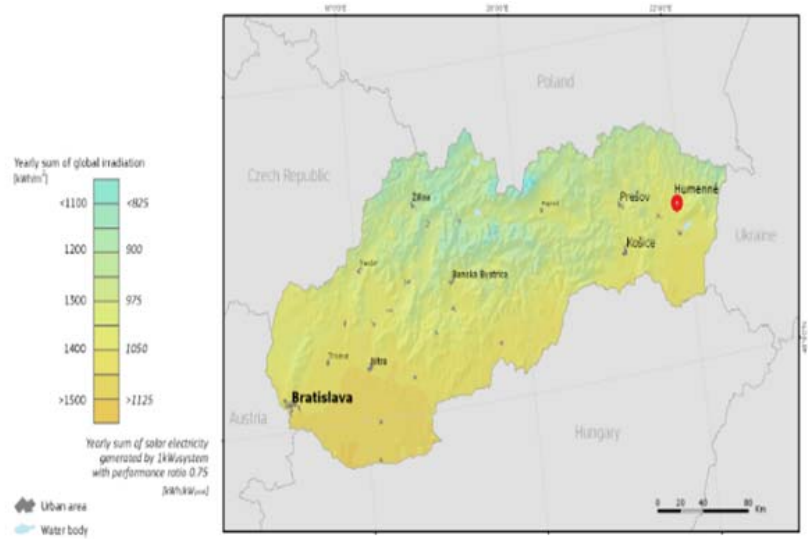

Figure 5. Location of the examined family house and yearly sun of global irradiation

\section{Design of a Basic Ceramic Roofing Bramac Braas Turmalín:}

The Bramac Braas Turmalín roofing consists of shape-accurate tiles together with an original system of accessories that ensure maximum functionality of the roof and the solution of every detail. Thanks to its robustness, Bramac Braas will provide perfect protection against extreme weather conditions.

The final price of a complete roofing with Bramac Braas ceramic roofing is $13846.80 €$ incl. VAT (Table. 1).

Table 1. Price of a complete roofing with Bramac Braas ceramic roofing

\begin{tabular}{||c|c|}
\hline & $\begin{array}{c}\text { Ceramic roofing Bramac Braas } \\
\text { Turmalín }\end{array}$ \\
Price without VAT & $11539 €$ \\
Price with VAT & $13846.8 €$ \\
Subsidies & $0 €$ \\
Final price with & $13846.8 €$ \\
VAT & \\
\hline
\end{tabular}

The following solar solutions were subsequently applied to the basic ceramic roofing:

Design of solar solutions:

\section{Design of Solar System Bramac BSD 6E PRO:}

In our case, it is an integrated solar system for a sloping roof for DHW heating. We will use the BSD E6 PRO collector which will be placed on the southfacing part of the roof and a 500-liter solar tank with a pump group. The basic offer also includes recommended accessories for connection, mounting of the collector on the roof, pressurization and connection of the solar to the DHW.

The price offer for this type of solar collector with the mentioned output and accessories is $5449 €$ with VAT. The price includes the subsidy, which is $3699 €$ with VAT. After adding the price of Bramac roofing, the final price of roofing and solar system is 17545.8 with VAT (table 2).

Table 2. Price of the Solar system Bramac BSD 6E PRO

\begin{tabular}{|lc||}
\hline & Bramac solar collectors \\
Price without VAT & $4541 €$ \\
Price with VAT & $5449 €$ \\
Subsidies & $1750 €$ \\
Ceramic roofing Bramac & $13846.8 €$ \\
Braas & $17545.8 €$ \\
Final price with VAT & \\
\hline
\end{tabular}




\section{Design of the Bramac Waris WRS250 Photovoltaic System:}

The Bramac Waris photovoltaic system is a roofmounted type of photovoltaic system for a pitched roof. It is suitable for all types of sloping roofs. It allows installation on all types of roofing, in new buildings and reconstructions. It consists of modules that consist of polycrystalline solar cells with threebus technology. The family house that has been selected requires the following items to install this photovoltaic system: 10 pieces of Waris-WRS250ST60F, $250 \mathrm{Wp}$, set of supporting structures for a sloping roof $2.5 \mathrm{kWp}$, inverter FOTOCONTROL $1 \mathrm{f}$ 230/275 DC 3.3 kW, AC/DC switchboard, RM Web monitor, RM SVR10 continuous power controller, cabling. The final price also includes installation and overhead costs. The assembly only needs to be carried out in one phase.

The final price, including installation, overhead costs and complete roofing with Bramac ceramic roofing is $17116.88 €$ with VAT (Table 3 ).

Table 3. Price of the Bramac WarisSolar WRS250 photovoltaic system

\begin{tabular}{|lc||}
\hline & $\begin{array}{c}\text { Roof-mounted } \\
\text { photovoltaic modules } \\
\text { Bramac }\end{array}$ \\
Price without VAT & $4850.07 €$ \\
Price with VAT & $5820.08 €$ \\
Subsidies & $2550 €$ \\
Ceramic roofing Bramac & $13846.8 €$ \\
Braas & $17116.88 €$ \\
Final price with VAT & \\
\hline
\end{tabular}

\section{Design of the Bramac InDaX Photovoltaic System:}

This photovoltaic system enables the integration photovoltaic crystallic modules into all roof coverings, where it takes over the protective function of the roof covering and produces solar energy from the Sun. It is suitable not only for new buildings, but also for reconstructions. It meets the required requirements for fire protection, water tightness and trouble-free ventilation. The accessories of the photovoltaic system for the selected family house consist of the photovoltaic modules Monier InDaX 255 Black, it also contains an integration set for a sloping roof $(2.55 \mathrm{kWp})$. RM Web monitor, AC/DC switchboard, RM SVR10 continuous power controller, cabling and connection. The module frame is made of anodized black aluminum.

The costs for the purchase, installation and transport of this system are $7,440.84 €$ with VAT, after deducting the state subsidy the costs are $4,890.84 €$ with VAT. The product is covered by a 10-year warranty and a 15-year warranty on linear power, which represents at least $80 \%$ of the rated power $(2.55 \mathrm{kWp})$. The final price, including installation, overhead costs and complete roofing with Bramac ceramic roofing, is $€ 17,594.20$ with VAT (Table 4).

Table 4. Price of the Bramac InDaX photovoltaic system

\begin{tabular}{|lc|}
\hline Price without VAT & $\begin{array}{c}\text { Built-in photovoltaic } \\
\text { modules Bramac }\end{array}$ \\
Price with VAT & $6200.7 €$ \\
Subsidies & $7440.8 €$ \\
Ceramic roofing Bramac & $2550 €$ \\
Braas & $12703.4 €$ \\
Final price with VAT & $17594.2 €$ \\
\hline
\end{tabular}

\section{Design of the Tegosolar Photovoltaic Roofing:}

Tegosolar PVL-68 is a photovoltaic roofing in the form of strips, which has excellent efficiency even in low intensity of sunlight. It is made of amorphous silicon, flexible and can be integrated into roofs of various inclinations (from 5 to $60^{\circ}$ ) and shapes. It has high efficiency even at lower conversion efficiency thanks to the three-layer system. It works even without direct sunlight (reaction to diffuse radiation) even with partial shading. The price of the Tegosolar product, including assembly, is $8,342.16 €$ with VAT, after deducting the subsidy from the state the price is $5,792.16 €$ with VAT. In combination with ceramic roofing, the final price is $€ 17,098.26$ with VAT (Table 5).

Table 5. Price of the Tegosolar photovoltaic roofing

\begin{tabular}{|ll|}
\hline Price without VAT & $\begin{array}{l}\text { Tegosolar photovoltaic } \\
\text { roofing } \\
6951.8 €\end{array}$ \\
Price with VAT & $8342.16 €$ \\
Subsidies & $2550 €$ \\
Ceramic roofing Bramac & $11306.1 €$ \\
Braas & $17098.26 €$ \\
Final price with VAT & 17 \\
\hline
\end{tabular}

\section{Results}

All prices of selected products are listed with VAT and without possible additional discounts offered by companies. From the graph in Fig. 6 it can be read that the resulting prices of roofing are almost the same. 


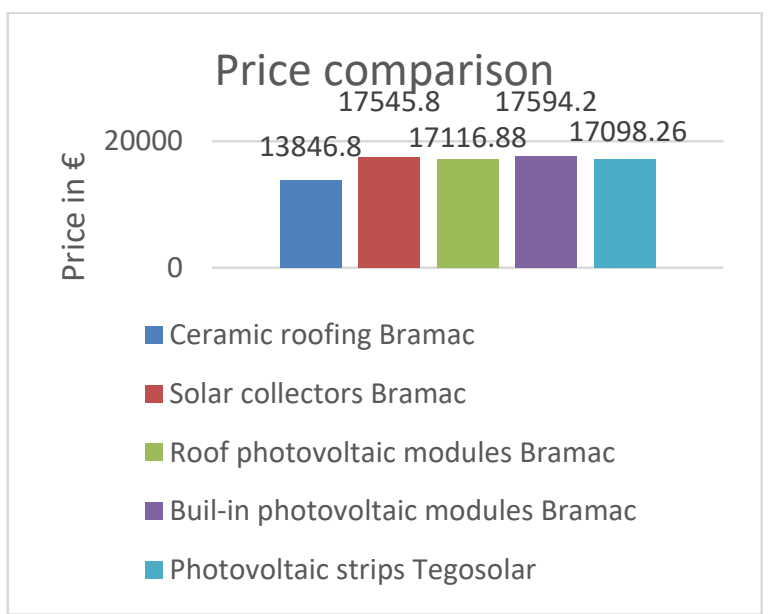

Figure 6. Comparison of the price of individual types of roofing

The most expensive types are built-in photovoltaic modules, followed by solar collectors with a $0.3 \%$ price difference, roof-mounted photovoltaic modules with $2.5 \%$ difference and the cheapest are photovoltaic strips by $3 \%$. Ceramic roofing is almost $20 \%$ cheaper than roofing that uses solar energy. However, this chart compares only the initial costs associated with the purchase and installation of roofing.

A very important factor in solar panels, photovoltaic modules and photovoltaic roofing is the return on investment, which is shown in the following graph (Fig.7).

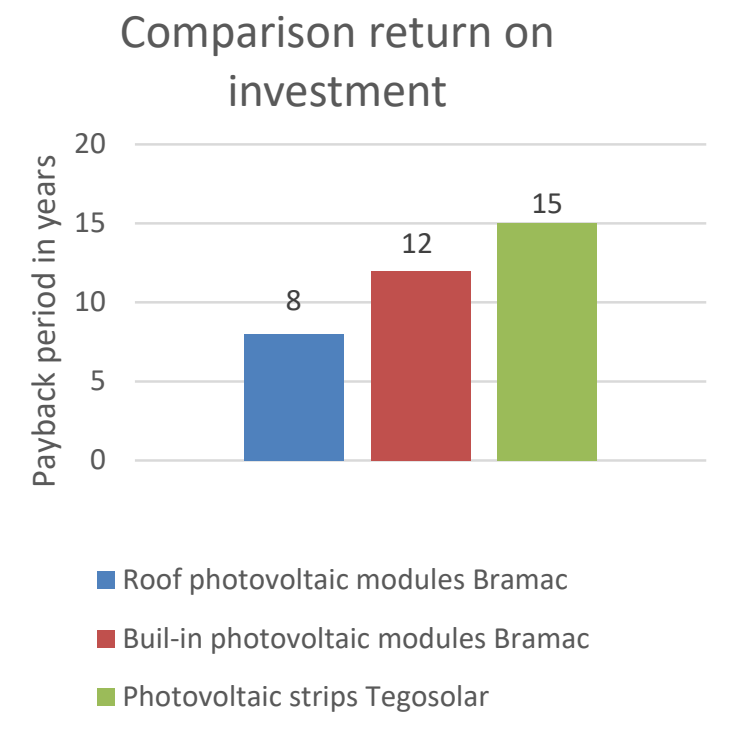

Figure 7. Return on investment of roof systems

When comparing the return, we can see more significant differences. The fastest return on investment from roof-mounted photovoltaic modules is in 8 years, this is followed by a return on built-in photovoltaic modules of 12 years and photovoltaic strips Tegosolar have the worst return of up to 15 years.
One of the important decision criteria is the service life of the roofing, a comparison of which is shown in Fig. 8.

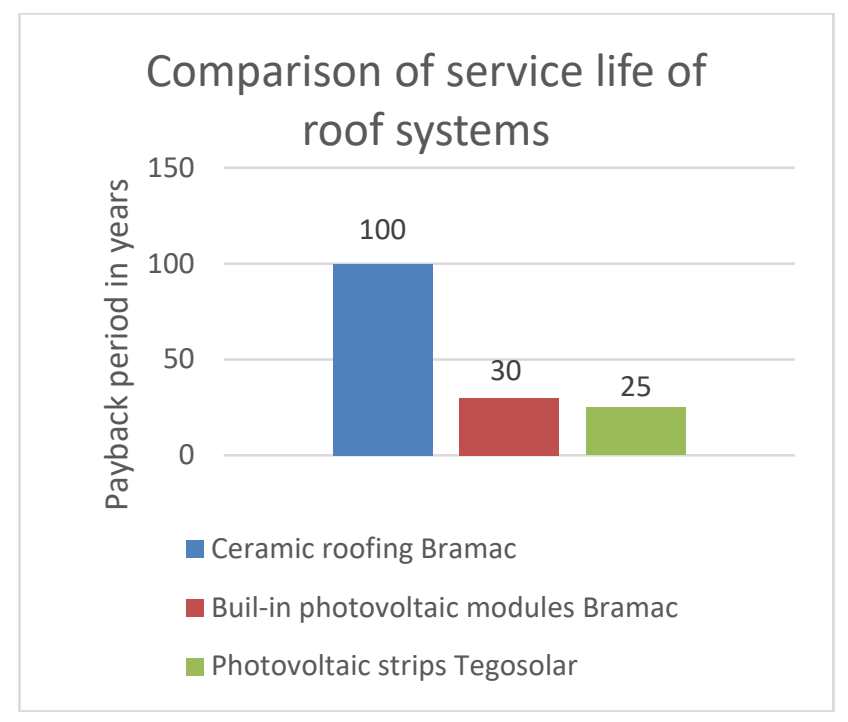

Figure 8. Service life of roof systems

\section{Conclusion}

If the most important criterion for the investor when choosing the roof covering of a family house is the price, then the most suitable choice is just ordinary roofing, in our case ceramic roofing. In this case, the initial costs are the lowest, the longest service life and it is not necessary to replace the covering during its use due to a malfunction. One of the advantages of ceramic roofing is the aesthetic impression, as the roof is uniform without disturbing elements, but does not have the function of producing electricity.

If the consumer is looking at the environment, environmental aspects and the renewable nature of the energy source and at the same time wants to save on bills, it is advisable to use solar energy. Once the investor decides that solar energy is the ideal solution for him, he has to answer basic questions, such as how to use solar energy. Solar collectors that directly heat the water are sufficient for water heating. Photovoltaic products are use of solar energy for electricity generation. Photovoltaic products produce electricity that can be used in the home from several perspectives. The amount of the subsidy from the state is the highest for photovoltaic products.

The article compared photovoltaic systems mainly in terms of price, return on investment, service life, aesthetics and ability to use solar radiation. The resulting comparison concluded that not only the duration and complexity of installation, but also the service life and price of solar products is equally important. An interesting result, however, is the return on the investment, where there are significantly higher differences, which can be an 
important indicator for a potential investor due to almost the same initial costs. In comparison of solar products with ceramic roofing in terms of the return on the investment, aesthetics and price, the clear winner is ceramic roofing. It is possible to expect that the price of photovoltaic roofing will decrease, and thus its availability and expanded will increase.

\section{Acknowledgements}

The authors are grateful to the Scientific Grant Agency of the Ministry of Education, Science, Research and Sports and of the Slovak Academy of Sciences (Grant No. VEGA - 1/0557/18 Research and development process and product innovations of modern methods of construction in the context of the Industry 4.0 principles) for financial support of this work.

\section{References}

[1]. Yergin, D., \& Gross, S. (2012). Energy for economic growth: energy vision update 2012; industry agenda. World Economic Forum.

[2]. Hussain, M. I., Ménézo, C., \& Kim, J. T. (2018). Advances in solar thermal harvesting technology based on surface solar absorption collectors: A review. Solar Energy Materials and Solar Cells, 187, 123-139.

[3]. Psimopoulos, E., Bee, E., Widén, J., \& Bales, C. (2019). Techno-economic analysis of control algorithms for an exhaust air heat pump system for detached houses coupled to a photovoltaic system. Applied energy, 249, 355-367.

[4]. Panos, E., \& Margelou, S. (2019). Long-term solar photovoltaics penetration in single-And two-family houses in Switzerland. Energies, 12(13), 2460.

[5]. Martinopoulos, G. (2018). Life Cycle Assessment of solar energy conversion systems in energetic retrofitted buildings. Journal of Building Engineering, 20, 256-263.

[6]. Kimura, K. I. (1994). Photovoltaic systems and architecture. Solar energy materials and solar cells, 35, 409-419.

[7]. Pandey, K. M., \& Chaurasiya, R. (2017). A review on analysis and development of solar flat plate collector. Renewable and Sustainable Energy Reviews, 67, 641-650.

[8]. Chmielewská, E. (2014). Environmental Zeolites and Aqueous Media: Examples of Practical Solutions. Bentham Science Publishers.

[9]. Mareddy, A. R., Shah, A., \& Davergave, N. (2017). Environmental impact assessment: theory and practice. Butterworth-Heinemann.

[10]. Huld, T., Salis, E., Pozza, A., Herrmann, W., \& Müllejans, H. (2016). Photovoltaic energy rating data sets for Europe. Solar Energy, 133, 349-362.

[11]. Gorjian, Shiva \& Shukla, Ashish. (2020). Photovoltaic Solar Energy Conversion: Technologies, Applications, and Environmental Impacts. Academic Press. 10.1016/C2018-0-05265-2.

[12]. MacKay, D. (2008). Sustainable Energy-without the hot air. UIT cambridge.

[13]. Xu, J., Yang, Y., Cai, B., Wang, Q., \& Xiu, D. (2014). All-ceramic solar collector and all-ceramic solar roof. Journal of the Energy Institute, 87(1), 4347. 